\title{
Perceptions of Islamic banking products: Evidence from Malaysia
}

\author{
Mustika RAHMI ${ }^{1}$, Nurul AZMA ${ }^{2}$, Fahd Mohammed OBAD ${ }^{3}$, Muhammad ZAIM ${ }^{4}$, Mahfuzur RAHMAN ${ }^{5}$ \\ Received: May 03, 2020. Revised: May 14, 2020. Accepted: July 05, 2020
}

\begin{abstract}
Purpose: Islamic banking products and services have always claimed to be unique from its traditional interest-based counterpart. However, in practice, many Islamic banks are alleged to have drifted away from its paradigm version. The purpose of this study is to gauge the perception of university students in Malaysia towards Islamic banking products. Research design, data and methodology: Data were collected from 250 Malaysian university students. Structural Equation Modeling (SEM) was performed to test proposed hypotheses to identify factors influencing customers' perception toward Islamic banking products. Results: The main finding indicates that most of the respondents are familiar with Islamic banking products and consider Islamic banking products as useful as its conventional counterparts. The regression results show that respondents are less convinced of adherence to Shari'ah, efficiency and helpfulness of existing Islamic banks. Conclusions: This is a cue to the Islamic banks' stakeholders that they need to realign their practices in an ethically responsible way in accordance with Shari'ah if they wish to secure existing customers and attract potential ones. In a competitive banking environment, most banks provide efficient and readily available service; thus, focusing on this as a strategy hardly distinguishes an Islamic bank from an interest-based bank
\end{abstract}

Keywords : Islamic Banking Products, University Students' Perception, Shari'ah Compliance, Issues of Islamic Banking.

JEL Classification Code: G21, A22, D12, N25

\section{Introduction}

Islamic banking is a banking system that offers Islamic banking products and services based on Islamic law (Shari'ah). The jurisprudential wing of Islam that deals with Islamic Banking is known as Fiqh Muamalat. Banking

1 Master student, Faculty of Economics and Management Sciences, International Islamic University Malaysia, Gombak, Selangor, Malaysia. Email: mustika.rahmi@gmail.com

$2 \mathrm{PhD}$ candidate, Institute for Advanced Studies (IAS). University of Malaya, 50603 Kuala Lumpur, Malaysia.

Email: nurulazma87@gmail.com

3 Master student, Faculty of Economics and Management Sciences, International Islamic University Malaysia, Selangor, Malaysia. Email: fahd@gmail.com

4 Master student, Faculty of Economics and Management Sciences, International Islamic University Malaysia, Selangor, Malaysia. Email: zaim@gmail.com

5 Corresponding author, Senior Lecturer, Faculty of Business and Accountancy, University of Malaya, 50603 Kuala Lumpur, Malaysia. Email: mahfuzur@um.edu.my

(c) Copyright: The Author(s)

This is an Open Access article distributed under the terms of the Creative Commons Attribution Non-Commercial License (https://creativecommons.org/licenses/by-nc/4.0/) which permits unrestricted non-commercial use, distribution, and reproduction in any medium, provided the original work is properly cited
mich permits unrestricted non-commerial use, practices under Islamic jurisprudence are allowed strictly on a profit-loss-sharing basis. Interest free banking is a narrow concept denoting a number of banking instruments or operations, which avoid interest and unethical practices. Recent decades witnessed a surge of interest in Islamic financial products, arguably due to increasing awareness among Muslims regarding implication of riba (interest) based transactions in Islam. This has spurred a growing shift from debt-based financing to equity-based financing. This aspect has been welcomed by the financial actors owing to Islamic Banking's ethical practices and diversified tools of risk minimization (Khan \& Bhatti, 2008).

A study by Siddiqui (2002) points out that the profit-losssharing scheme enables Islamic banks to lessen the impact of adverse economic conditions on the asset side of balance sheet. On the contrary, some scholars highlight that, in practice, the profit-loss-sharing principle appears to be a mirage (Khan, 2004). He shows that only a negligible part of assets in Islamic Banks (5\%) comprise of true Profit and Loss Sharing ("PLS") based loans. The remaining (95\%) are murabaha, which is essentially debt-based financing. Adding to the controversy, some studies have shown deviation paradigm version in both debt and equity based 
products. In particular, mudaraba,which is supposed to be interest-free, is in effect a copy of conventional demand deposits (Chong \& Liu, 2007). On the positive side, Dusuki and Abdullah (2006), Siddiqui (2002), and Haron and Hisham (2003) highlight the socially responsible role of Islamic financial institutions via promoting welfare and equitable distribution of resources. Isma'il (2002), however, contends that Islamic banks should target profit maximization and not social welfare-like conventional banks - but within the framework of Islamic law. Based on the past studies, the role and practices of Islamic banks in the society is controversial. In addition, in today's age of economic growth and fierce competition, Islamic Banks are being forced to prioritize profit over social welfare simply as a means to survival. Thus, the question arises whether Islamic banking practices today truly in line with Islamic law.

This paper seeks responses from university students in Malaysia to measure the general perception of Islamic Banking products and practices. To this effect, the paper surveys existing literature regarding Islamic Financing and offers a critical analysis of the findings. The outcome of this research will be of interest to university students and faculty, Malaysian banking regulators, and future researchers. Islamic banking products are getting popular among all races in Malaysia regardless of their religion. However, there are some issues that are obvious to those who have knowledge about Islamic transaction. Many people from different races and religions are using Islamic banking products due to its competitive advantage as compared to conventional products. However, people who have basic knowledge about Islam are not convinced by the contemporary Islamic products due to its similarity with the conventional banking products. Many people believe that Islamic products are the carbon copy of the conventional banking products. They want to use products in compliance with Shari'ah in order to avoid uncertainty and riba in their transactions. Since Islamic banking products are in high demand by the customers, it is hoped that the future prospects will be greater in its demand and quality of products. The rationale behind this research is to understand the weaknesses of the Islamic banking products and provide recommendation to make the products more consumerfriendly.

The customer perception is often identified by their level of satisfaction towards particular products or services, and customer satisfaction is usually measured in terms of service quality and service features offered by an institution (Rustam, Bibi, Zaman, Rustam, \& Haq, 2011). Prior studies about Islamic banking products have mainly focused on corporate customers (Ahmad \& Haron, 2002; Rustam et al., 2011). However, very few of these articles have specifically focused on the students' perception. They will realize many
Islamic banking products in the market when they face real world after graduating. For example, they may have to open new accounts when getting a job. They will find many products that are offered by the banks. Moreover, many of them may not know the difference between savings and current accounts, especially for those who never learned about the banking system in their study. They also may experience having insurance, financing products, and investment. Since the young generation are the future prospects in the economy, the main objectives of this study is to highlight their perception towards the Islamic banking products, especially those who have at least basic knowledge about Islamic banking transactions. Hence, this study aims to find out the perceptions of university students about the Islamic banking products, to review the growth of Islamic banking in Malaysia and to offer suggestions for improvement based on the evidence provided by literature studies.

The remainder of the paper has been organized as follows: Section 2 provides literature review. Research methodology is discussed in section 3. The findings and analysis are explained in section 4 , and the conclusion is presented in the final section.

\section{Literature Review}

Islamic Banking has been defined in a multitude of ways by experts. Nonetheless, there is a consensus in Academia that Islamic Banking is based on Islamic Shari ah law, according to the tenets of Fiqh Mu'amalah (rules of transaction). Islamic Banking is defined as a system of banking activity consistent with principles of Islamic Shari ah and its application to implementation of an Islamic economy. An Islamic Bank can, thus, be termed as a financial intermediary, a custodian of people's money and wealth, which diverges from conventional banks in that its payoff to clientele is in form of profit sharing (or loss), while the principles of Shari'ah dictate its operations (Dar \& Presley, 2000). It is a popular notion among orientalists that Islamic Banking is concentrated around the prohibition of business related to interest, alcohol, gambling, pork, etc (Woodley, 2009). On the contrary, in the Muslim world, only the prohibition of Riba is perceived as the defining feature of Islamic financing (Dusuki, 2008).

It is noteworthy that a ban on riba is just one of the features of Islamic banking. It also proscribes unjustified risk-taking (gharar), recklessness, exploitation of ignorance (jahl), and gambling (maysir). Moreover, Islamic banking administers its operations in an ethically responsible and Shari ah compliant manner (Iqbal, 1997). These principles are derived from the axiom of justice, fairness and equality enshrined by Qur'an and Sunnah. There is considerable 
debate in the academic community as to what the ideal objective of an Islamic financial institution should be. Ahmad (200), Siddiqui (2002), and Bakar (2003) claim that profit-loss-sharing is the sole principle that reflects the true spirit of Islamic Banking. They also state that Islamic banks should not be only profit-oriented and must promote Islamic values and norms to achieve the objectives of an Islamic economy. Khan (2007) reinforces this by arguing that Islamic banks should prioritize Islamic principles over profit because their clienteles' preference for them is solely for religious causes. On the other hand, a group of scholars point out that no Quranic text overemphasizes the profitloss-sharing model and, thus, should not be the primary goal of an Islamic bank. Satkunsegaran (2003), Dusuki and Abdullah (2006) underscored the importance of Islamic banks pursuing profit maximization tactics to ensure longterm sustainability in modern competitive industry. Thus, they emphasize the importance of entering into debt-based contracts like conventional banks to bolster earnings. Islamic banks and finance companies use non-tradable instruments, distinct from debt instruments commonly used by interest-based financial institutions (Hassoune \& Volland, 2006). Sincre riba (interest) is forbidden in Islam, all Islamic banking products are mainly based on profitloss-sharing principle. Some of the notable products and services are mentioned henceforth. Mudaraba is an equity based instrument, aimed at financing a specific project of a client. Under Mudaraba, the bank provides the capital, while technical expertise and operational logistics are carried out by the client. The bank is not allowed to interfere with the business operations.

Thus, the bank and client become temporary partners, where the bank is entitled to a management fee, and, according to a pre-determined ratio, profit is shared between parties, while all losses are carried by the bank. (Zaher \& Hassan, 2001). In musharaka financing, the financial institution and client enter a partnership to contribute toward capital and entrepreneurship. Both parties combine their financial resources, form a joint venture, and manage it accordingly. Zaher and Hassan (2001) favor musharaka among different modes of financing because it conforms to profit-loss-sharing principle more than other options. Simply, murabaha is a cost-plus or mark-up contract. In this contract, the financial institution purchases asset(s) on behalf of the client and sells it to the client at a pre-determined price, involving a negotiated profit margin. Murabaha is criticized by many scholars (Homoud, 1994; Gafoor, 1999; Khan \& Bhatti, 2008) for gross violation of Shari ah principles. In ijara mode of financing, a client approaches a bank after having identified an asset required for a project. The bank purchases the asset and transfers possession to the client under a lease contract. Over the term of the ijara, the client pays a rental fee; at the end of period, the client reverts the asset to bank or takes ownership under the terms of lease. Ijara is allowed by Shari ah under the condition that the bank retains risk of asset ownership and bears costs associated with damages, repairs, insurance and depreciation (Zaher \& Hassan, 2001).

The key agent of controversy surrounding practices and products of Islamic Banking stem from the aversion of Islamic Banks to employ the quintessential PLS principle. While even the orientalist scholars concede the theoretical superiority of Islamic banking paradigm, the overt dependence of Islamic Banks on debt-based instruments has led to mixed perception in academia and among public. Nienhaus, in a 1986 study, remarked that very few Islamic banks truly follow the profit-loss-sharing system. This was supported by findings of Obaidullah (1999), and Khan and Ahmed (2001). In recent times, equity based financing instruments like Mudaraba and Musharaka are least frequently used by Islamic Banks (Lewis \& Algaus, 2001; Kuran, 2004; Iqbal \& Molyneux, 2005).

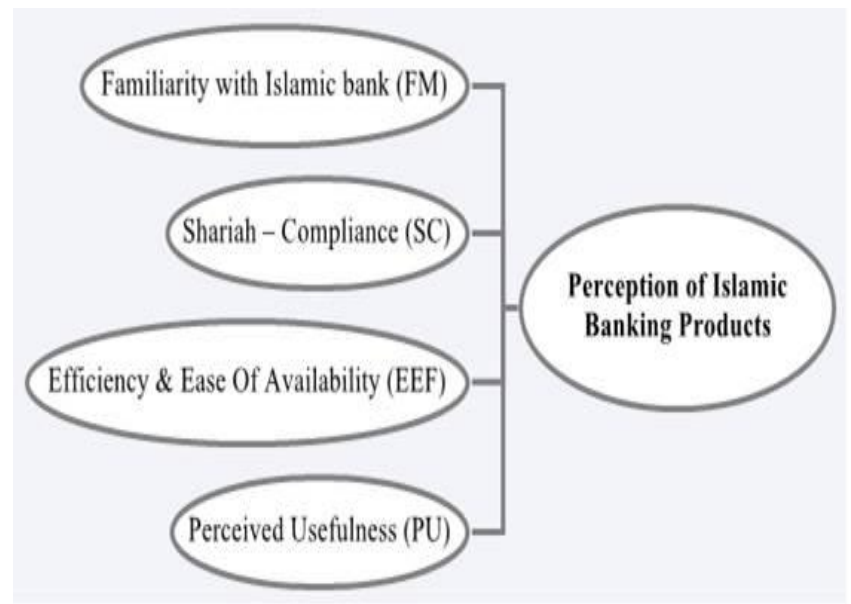

Figure 1: Research framework

Even more alarmingly, Yousef (2004) highlights a tendency among Islamic banks to enter contracts similar to debt in provisions of financing; he calls it the murabaha syndrome. Ahmad (1994), Siddiqui (2002) and Warde (2004) also observed a growing trend of Islamic banks structuring balance sheet based on debt instruments. This criticism is not new. Nienhaus (1986) had forecasted this situation and predicted that this would be an inevitable result of Islamic banks operating in a mixed economy and constantly competing with traditional banks. He further points that whereas conventional banks know exact figures of their earnings, profit-loss-sharing barely allowed Islamic banks to get a rough estimate of future profits, making strategizing and profit-maximization difficult. In addition, high concentration of Mudaraba and Musharaka could result in undertaking riskier projects and thus threatening the long-term viability of the bank. Khan (2004) counters Nienhaus's argument stating that the resemblance of 
Islamic banking products to conventional banks is deceptive, and it doesn't necessarily mean that Islamic banking products are impermissible by Shari ah. He posits that even for products that are identical, it is the set of process that distinguishes a halal (permitted) banking product from haraam (not permitted).

\section{Methodology}

This study employed primary data to measure the perception toward Islamic Banking products among university students. Thus, a set of questionnaires was prepared for the purpose of collecting the data and then distributed randomly among 250 university students. Information from academic journals, books, articles, theses and website information was accessed using secondary method of data collection. Primary data, on the other hand, was used to elicit the respondents' opinion regarding the factors that are affecting their perception toward Islamic Banking products. Furthermore, the data collected was subjected to statistical analysis using the statistical package for social sciences (SPSS) version 19. Factor analysis and structural equation modeling were employed to find out factors that influence respondents' view toward Islamic Banking products.

This study focuses on the relationship between factors that affect the perception of Islamic banking products among university students. Thus, the theoretical framework of this study is defined as follows in figure 1 :

Four hypotheses are developed to address the research questions, namely:

H1: There is a positive correlation between Perceived Usefulness (PU) and perception of Islamic banking products.

H2: There is a positive correlation between Shariah Compliance (SC) and perception of Islamic banking products.

H3: There is a positive correlation between Familiarity (FM) and perception of Islamic banking products.

H4: There is a positive correlation between Efficiency/Ease of Availability (EEF) and perception of Islamic banking products.

For the purpose of conducting this study, a set of questions consisting of three parts has been prepared. The questionnaire begins with the first part that procures the demographic information, namely, gender, age, race, marital status, respondents' kuliyyah, level of study and monthly income. Second section of the questionnaire is formulated to obtain general information regarding Islamic bank. The main body of the questionnaire - section threeconsists of five important elements which are categorized as perceived usefulness, Shariah-compliance, familiarity with Islamic bank, efficiency or ease of availability and perception of Islamic bank. The perceived usefulness measures respondents' views as to whether Islamic banking benefits them with regard to safeguarding their wealth, and is cost-efficient. Further extension has been done in terms of Shariah-compliance issue that focuses on the compatibility of prevalent Islamic banking practices with Qur'an and Sunnah. It also investigates as to whether Islamic banking operations prioritize pursuit of profit over social welfare. Familiarity aspect of the questionnaire focuses on the understanding of respondents about Islamic bank; it has to do with reputation and image of the Islamic bank in the view of university students. The efficiency or ease of availability section zooms into the Islamic banking services such as ATM machine and internet banking. It focuses on user-friendly aspect, transaction process and information about Islamic banking product offers to respondents. Finally, the perception section of the questionnaire combines all the factors including perceived usefulness, Shari ah-compliance, familiarity and efficiency. These factors are expected to provide the respondents with good perception on Islamic bank and establish beliefs on Islamic bank as an alternative to conventional banks. All of these questions have been asked in ordinal type data and the answers are ranked with scores 1 to 5, ranging from strongly disagree to strongly agree. A set of 271 questionnaires were distributed to university students in Kuala Lumpur. This sample has been taken randomly from different level of students, (Bachelor, Master or $\mathrm{PhD}$ ) and from different faculties.

In this study, perception of Islamic banking products is defined as endogenous variable, while perceived usefulness, Shari'ah-compliance, familiarity, and efficiency/ease of availability are defined as exogenous variables. Analysis of Moment Structure (AMOS) software has been used in evaluating the model. The SEM model does include another form of test. The Confirmatory Factor Analysis, (CFA) is a model that measures relationship between observed and latent variables. One of the measurements is Comparative Fit Index (CFI), which is equal to discrepancy function adjusted for sample size. The index ranges from 0 to 1 , with a larger value reflecting a better model fit. Another important test employed is Root Mean Squared Error of Approximation (RMSEA). RMSEA concerns with the residual inside the model. As with CFI, it ranges between 0 to1. However, smaller value indicates good fit for this model. Last but not least, Chi - square test is also utilized, which highlights the difference between expected and observed covariance matrices. The steps to perform SEM start with the specification of a model to be estimated. The 
model tested is a statistical statement about the relations among variables (Hoyle, 1996). Next step is to test the goodness-of-fit of the model proposed. Thirdly,the relationship among the variables were tested through some measurements and subsequently reported the results in relation with the model tested.

\section{Results and Discussion}

This study has used several parts of variables to measure the perception of Islamic banking products among university students. There are nine nominal (categorical) variables including gender, age, race, marital status, faculty, education level, monthly income, use of Islamic Banking and knowledge. The respondents comprise of 121 males and 100 females. Of them, the majority are Malay (103 respondents); the second largest race-group is Indian (60 respondents), and the rest are African (36 respondents), Arab (14 respondents) and Chinese (8 respondents). The age of the respondents are categorized into four groups: 20 and below, 21-26 years old, 27-35 years old and 36 and above. Most of respondents (51.1\%) are 21-26 years of age, while the second largest $(27.1 \%)$ are between $27-35$ years of age, followed by the third largest $(20.4 \%)$ consisting of 20 years old and below. Only $1.4 \%$ of the respondents are aged 36 and above. There are $87.1 \%$ of respondents who are currently single, and the rest are married.

The survey was distributed to the university students enrolled in various faculties including Economics, Engineering, Human Science, Education, and ICT, among others. The proportion of respondents, according to their qualification, shows that around $47.5 \%$ are currently pursuing undergraduate degrees, while $32.6 \%$ masters and the rest $(19.9 \%)$ doctorate degrees. The monthly income section of the questionnaire is divided into four parts. 123 respondents reported to have income of less than RM 500, while 46 respondents reported to have income range of RM 600- 1000. The third largest number (31 respondents) reported to have income of RM $1100-2000$, and the highest income earner in the category (greater than RM2000) was reported by 18 respondents.

The purpose of the survey is to measure the perception of Islamic banking products among university students. Respondents who use Islamic banking accounted for $75 \%$ or around 166 persons, while the rest who chose nonIslamic banking accounted for $24.9 \%$. Furthermore, the respondents who are knowledgeable about Islamic banking accounted for $67.4 \%$, while the rest reported to having no decent knowledge about Islamic banking. Table 1 shows the factor loadings for the rotated factors, which indicate how closely the variables are related to each factor. The first factor consists of five of the twenty one variables.
These variables have positive loadings and address Perceived Usefulness (PU). The second factor, consisting of four variables, is Shari ah-compliance (SC) because all items are related with Islamic law. The third factor includes five variables, termed Familiarity (FM). The fourth factor under Efficiency and Ease of Availability (EEF) consists of four variables, while the last factor namely Perception (DV) includes four variables.

Table 1: Factor loading

\begin{tabular}{|c|c|}
\hline Components & Factor Loading \\
\hline \multicolumn{2}{|l|}{ Perceived Usefulness } \\
\hline IB is economical & 0.703 \\
\hline IB has less cost & 0.538 \\
\hline IB gives safe control over wealth & 0.763 \\
\hline IB has several types of benefits & 0.854 \\
\hline \multicolumn{2}{|l|}{ Shariah Compliance } \\
\hline IB product is equal to conventional & 0.701 \\
\hline IB in line with Qur'an \& Sunnah & 0.811 \\
\hline IB isn't truly $100 \%$ halal & 0.75 \\
\hline IB focuses on profit & 0.621 \\
\hline \multicolumn{2}{|l|}{ Familiarity } \\
\hline I understand IB concept & 0.659 \\
\hline IB involves interest reward system & 0.681 \\
\hline IB is only for Muslim & 0.683 \\
\hline IB involves profit \& loss sharing principle & 0.712 \\
\hline IB is more unique than conventional & 0.655 \\
\hline \multicolumn{2}{|l|}{ Efficiency \& Ease Of Availability } \\
\hline Riba is prohibited & 0.674 \\
\hline $\begin{array}{l}\text { There's long queue to do transaction in IB } \\
\text { counter }\end{array}$ & 0.659 \\
\hline $\begin{array}{c}\text { There are lot of details to fill up to open an IB } \\
\text { account }\end{array}$ & 0.559 \\
\hline IB ATM is user friendly & 0.683 \\
\hline \multicolumn{2}{|l|}{ Perception } \\
\hline IB staffs are helpful & 0.797 \\
\hline IB products are useful & 0.771 \\
\hline IB products are efficient & 0.669 \\
\hline $\begin{array}{c}\text { Familiarity encourages people to use IB } \\
\text { products }\end{array}$ & 0.692 \\
\hline
\end{tabular}

Table 2: Reliability test

\begin{tabular}{|c|c|}
\hline Dimension & Cronbach's Alpha \\
\hline Perceived Usefulness & 0.782 \\
\hline Shari ah-Compliance & 0.859 \\
\hline Familiarity & 0.836 \\
\hline Efficiency \& Ease of Availability & 0.683 \\
\hline Dependent Variable & 0.745 \\
\hline
\end{tabular}




\subsection{Confirmatory Factor Analysis (CFA) Model}

A measurement model was developed to examine validity of all the exogenous and endogenous variables; furthermore, it was also tested for fitness requirements. The constructs consist of (PU), (SC), (FM), and (EEF) as exogenous variables and perception of Islamic banking products as endogenous variables. The measurement model for all the latent variables was fit at a CFI with a value of .958. RMSEA, which refers to fit per degree of freedom of the model, shows an acceptable value of 0.045 . The RMSEA rule of thumb mentions that the acceptable value is below 0.08. The Chi-Square of the model shows the value of 228.908 while the degree of freedom (DF) equals to 158. The value of Chi-Square divided by DF is 1.449 , which means lower than the cut-off value $(<0.5)$; the value shows the goodness-of-fit of the model. In terms of the correlation between all latent variables, all of the exogenous and endogenous variables have the value less than the cut-off of 0.85, which approves the discriminant validity between variables. In other words, the measurement model has achieved the discriminant validity. The highest correlation is shown by the FM to the Islamic products.

Table 3: Model fit

\begin{tabular}{|c|c|c|}
\hline Measures & Value & Interpretation \\
\hline CMIN & $p$ value $>.05$ & $\begin{array}{c}\text { Accept the goodness-of-fit of the } \\
\text { model }\end{array}$ \\
\hline TLI & $(\geq .90)=.958$ & $\begin{array}{c}\text { Accept the goodness-of-fit of the } \\
\text { model }\end{array}$ \\
\hline CFI & $(\geq .90)=.949$ & $\begin{array}{c}\text { Accept the goodness-of-fit of the } \\
\text { model }\end{array}$ \\
\hline RMSEA & $(\leq .08)=.045$ & Accept the goodness-of-fit of the \\
model
\end{tabular}

Notes: $\quad$ CMIN = the value of chi-square; TLI = Tucker-Lewis Index; $\mathrm{CFI}=$ Comparative Fit Indices; RMSEA = Root Mean Square Error of Approximation

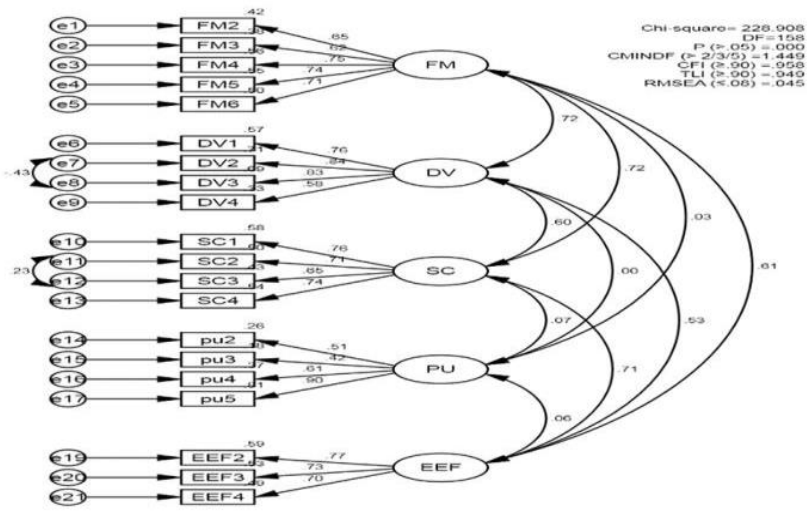

Figure 2: CFA model of the dimensions
The first factor is FM with five indicators, and the second is DV along with its four predictors. Next is SC and its constituent 4 predictors. The fourth factor is PU with four predictors, and the last is EEF with three predictors. Table 6 shows that this CFA model has met the requirement for the goodness of fit test. The correlation value of 0.72 between FM and DV, along with FM and SC, is observed as the highest correlation. Moreover, FM3 ("IB involves interest reward system") and SC1 (IB product is the same with conventional) are the most significant predictors among other predictors of each variable. The second highest correlation of 0.71 was exhibited by the correlation between DV and EEF with the DV2 ("IB products are useful") and EEF2 ("There's long queue to do transaction in IB counter") as significant predictors. The third strongest correlation is shown by the relationship between FM and EEF. The most significant predictor for PU is PU5 ("IB has several types of benefits"). However, PU value does not show any significant correlation with any other variables.

The findings also demonstrate a correlation between the four independent variables and a dependent variable. It can be seen that there is 0.72 of correlation between FM (Familiarity) with DV (Perception), while the correlation between SC (Shari'ah compliant) and DV is 0.60. However, there is no correlation between PU (Perceived Usefulness) and DV. The EEF (Efficiency \& ease of availability) variable has a 0.71 correlation with the DV. Thus, this indicates that However, the hypothesis that there is correlation between perceived usefulness and perception of Islamic bank is rejected.

\subsection{Relationships among Latent Variables Using SEM}

The structural model for this study is represented in the Figure 2, as the four hypotheses of this study were tested in order to investigate the causal paths. It is considered above the cut-off value of 0.90 , and the RMSEA was significant at 0.049 , which means that the required value of RMSEA was achieved. Additionally, since the normed Chi-square should be less than 5, Chi-square/df in this case was of a value of 1.530, which contributed toward making the original structural model fit. And finally, the Chi-square was 244.864 with a degree of freedom of 160 value. Therefore, the original structural model was not in need for modifications.

Figure 3 shows the structural equation model: One latent variable predicted by four latent predictor variables; each latent variable has different number of indicators. It shows that the latent predictor variable of FM consists of five indicators, the SC comprises of four indicators. The PU variable has four indicators while the EEF is supported by 
three indicators. The model has a latent variable, called DV (Perception), which has been predicted by four latent predictor variables, which are FM (Familiarity), SC (Shari`ah-compliance), PU (Perceived Usefulness) and EEF (Efficiency \& Ease of availability). The negative coefficient of 0.03 was reported by PU. It indicates that a unitary increase in PU corresponds to a 0.03 times reduction in DV. On the other hand, an increase in FM will increase the DV by 0.58 times. A rise in SC will cause DV to increase by 0.10 times, and an increase in EEF will increase DV by 0.12 times.

Table 4: Model fit

\begin{tabular}{|c|c|c|}
\hline Measures & Value & Interpretation \\
\hline CMIN & $\mathrm{p}$ value $>.05$ & $\begin{array}{l}\text { Accept the goodness-of-fit of the } \\
\text { model }\end{array}$ \\
\hline TLI & $(\geq .90)=.940$ & $\begin{array}{l}\text { Accept the goodness-of-fit of the } \\
\text { model }\end{array}$ \\
\hline $\mathrm{CFI}$ & $(\geq .90)=.949$ & $\begin{array}{l}\text { Accept the goodness-of-fit of the } \\
\text { model }\end{array}$ \\
\hline RMSEA & $(\leq .08)=.049$ & $\begin{array}{l}\text { Accept the goodness-of-fit of the } \\
\text { model }\end{array}$ \\
\hline
\end{tabular}

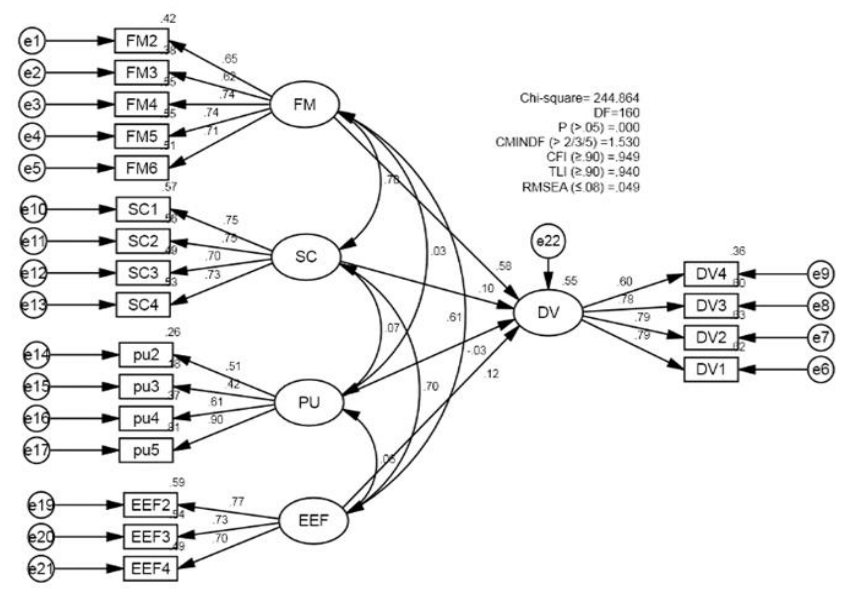

Figure 3: SEM for measuring perception of University students toward Islamic banking product. Standardized estimates

\section{Conclusions}

The objective of this paper was to examine the university students' perceptions regarding Islamic Banking and Financial products. In order to achieve it, empirical evidences have been provided; they show that most of the respondents are familiar with Islamic Banking products and consider Islamic banking products as useful in comparison to their conventional counterparts. While there is almost a consensus regarding utility of Islamic Banking and its status as a viable alternative to conventional banking, respondents are less convinced of adherence to Shari ah, efficiency and helpfulness of existing Islamic banks. This has had a negative impact in their overall perception. Also, since respondents are comparatively unconvinced of the Shari'ah compliance of prevailing Islamic banks, this phenomenon underscores the importance of implementing a proper profit-loss-sharing system in the current economic system, which will enable Islamic banks to garner more clientele to survive the competitive business environment.

This is a cue to the Islamic banks' stakeholders that they need to realign their practices in an ethically responsible way in accordance with Shari'ah if they wish to retain existing customers and attract new ones. Besides, in a competitive banking environment, most banks provide efficient and readily available service. Thus, focusing on this as a strategy hardly distinguishes an Islamic bank from an interest-based bank. As the paper finds, concentrating on Shari'ah compliance is the vital area, which the respondents had an inferior perception on Islamic banking. Regulators and bank owners ought to address this part.

Despite all the arguments posited above, it is necessary to acknowledge to limitations of this study. First, the sample size was quite small. The authors of this paper had attempted to contact students in other campuses but yielded little success in terms of response. Thus, the results may vary with a greater sample size. Next, the sample size consisted of a fairly homogenous demographic. This is not necessarily representative of all universities and colleges in Malaysia, notwithstanding the geographical variances too. A more detailed investigation of this issue is, therefore, open for future researchers to explore.

\section{References}

Ahmad, N., \& Haron, S. (2002). Perceptions of Malaysian corporate customers towards Islamic banking products and services. International Journal of Islamic Financial Services, 3(4), 13-29.

Ahmad, W. (2008). Islamic banking in the UK: Opportunities and challenges (M. Sc. Accounting and Finance Thesis). Kingston University, London, England. Retrieved from http://ssrn. com/abstract, 1349170.

Chong, B. S., \& Liu, M. H. (2009). Islamic banking: interest-free or interest-based? Pacific-Basin finance journal, 17(1), 125144.

Dar, H. A., \& Presley, J. R. (2000). Lack of profit loss sharing in Islamic banking: management and control imbalances. International journal of Islamic financial services, 2(2), 3-18.

Dusuki, A. W. (2008). Understanding the objectives of Islamic ba nking: a survey of stakeholders' perspectives. International Jo urnal of Islamic and Middle Eastern Finance and Managemen $t, 1(2), 132-148$. 
Dusuki, W. A., \& Abdullah, I. N. (2006). The ideal of Isla mic banking: chasing a mirage. Paper presented at INCEI F Islamic Banking and Finance Educational Colloquium, Kuala Lumpur, Malaysia.

Gafoor, A. A., \& Muslims, C. (1999). Islamic Banking \& Finance: Another Approach. Toronto, ON: Apptec Publications.

Haron, S., \& Hisham, B. (2003). Wealth mobilization by Isla mic banks: the Malaysian case. Paper presented at Interna tional Seminar on Islamic Wealth Creation, University of Durham, Durham, England.

Hassoune, A., \& Volland, E. (2006). Islamic finance comes of age. Bloomberg Businessweek - Markets and Finance. Retrieved from https://www.bloomberg.com/news/articles/2006-1026/islamic-finance-comes-of-agebusinessweek-business-newsstock-market-and-financial-advice

Homoud, S. H. (1994). Progress of Islamic banking: the aspiration $\mathrm{s}$ and the realities. Islamic Economic Studies, 2(1), 71-80.

Hoyle, R. H. (1996). Structural equation modeling: Concepts, issu es, and applications. Thousand Oaks, CA: Sage.

Iqbal, M. (1997). Islamic banking. In M. Kahf, (Ed.), Lesson $s$ in Islamic Economics (pp.493-524). Jeddah, Saudi Arabi a: Islamic Research and Training Institute.

Iqbal, M., \& Molyneux, P. (2005). Thirty Years of Islamic B anking: History, Performance and Prospects. New York, NY: Palgrave Macmillan.

Ismail, A. H. (2002). The Deferred Contracts of Exchange: Al-Quran in Contrast with the Islamic Economist's Theor $y$ on Banking and Finance. Kuala Lumpur, Malaysia: Isla mic Institute of Malaysia.

Khan, A. (2004). Is Islamic banking truly Islamic or is it jus $\mathrm{t}$ cosmetically enhanced conventional banking. Islamica $M$ agazine, (Summer/Fall).

Khan, M. M., \& Bhatti, M. I. (2008). Islamic banking and finance: on its way to globalization. Managerial finance, 34(10), 708725.

Kuran, T. (2004), Islam and Mammon: The Economic Predic aments of Islamism. Princeton, NJ: Princeton University $\mathrm{P}$ ress.

Nienhaus, V. (1986). Islamic economics, finance and banking: theory and practice. Journal of Islamic Banking and Finance, 3(2), 36-54.

Obaidullah, M. (1999). Capital adequacy norms for Islamic financ ial institutions. Islamic economic studies, 5(1), 63-80.

Abduh, M., \& Abdul Razak, D. (2012). Customers' attitude towards diminishing partnership home financing in Islamic banking. American Journal of Applied Science, 9(4), 593-599.

Rustam, S., Bibi, S., Zaman, K., Rustam, A., \& Haq, Z. U. (2011). Perceptions of corporate customers towards Islamic banking products and services in Pakistan. The Romanian Economic Jo urnal, 41(4), 107-123.

Satkunsegaran, E. B. (2003). Corporate governance and the protection of customers of Islamic banks. Paper presented at International Islamic Banking Conference 2003, Prato, Italy.

Siddiqui, S. H. (2001). Islamic banking: true modes of financing. New Horizon, 109(2), 15-20.

Warde, I. (2000). Islamic Finance in the Global Economy, E dinburgh, United Kingdom: Edinburgh University Press.

Woodley, S. (2009). Growing Interest in Islamic Finance. W ashington, DC: The Diplomatic Courier: A Global Affairs Magazine.

Yousef, T. M. (2004). The Murabaha syndrome in Islamic finance : laws, institutions and politics. The politics of Islamic finance, 63-80.

Zaher, T. S., \& Kabir Hassan, M. (2001). A comparative literature survey of Islamic finance and banking. Financial Markets, Institutions \& Instruments, 10(4), 155-199. 